\title{
TAXONOMIC STUDY OF LICHENS OF PHULCHOWKI HILLS, LALITPUR DISTRICT (KATHMANDU VALLEY)
}

\author{
A. Devkota \\ Central Department of Botany, Tribhuvan University, Kirtipur, Kathmandu, Nepal. \\ Email:devkotaa@hotmail.com
}

\begin{abstract}
The lichens were collected from different altitudinal gradient ranges from 1500-2700 m. above sea level of Phulchowki hill. They were identified on the basis of their morphological, anatomical and chemical studies (colour reaction, thin layer chromatography and microcrystallography). A total of thirty-two species of lichens were identified which comprises nine families and ten genera. Among them family Parmeliaceae was largest one which comprises ten species.
\end{abstract}

Key words: Lichens; Crustose; Foliose; Fructicose.

\section{INTRODUCTION:}

There are about twenty thousands species of lichen in the world according to the estimation of Zahlbruckner (1922-1940), Lamb (19630) and Rogers (1977). Sharma (1995) estimated two thousand species of lichen in Nepal representing ten percent of the total lichens of the world. Sharma (1995) enumerated four hundred sixty five species of lichens in Nepal.Bania (1996) enumerated ninety-nine species of lichens from Shivapuri and Sikles.Likewise Pathak (1998) enumerated fifty-two species of lichens from Hetauda and Dang. Devkota (1999) enumerated fifty-five species of lichens from Namobuddha, Kavrepalanchok.Even though Nepal is rich in lichen flora, but most part of which remain lichenologically unexplored. It is felt that it is an important to make complete study on plant kingdom, so this study may contribute little support in this connection.

The objective of this research is taxonomic study of lichens found in Phulchowki hill.

\section{MATERIALS AND METHODS:}

Materials were collected from Phulchowki hill during January 2005.Lichens were collected by sampling $10 \mathrm{~m} \times 10 \mathrm{~m}$.quadrat and $5 \mathrm{~m} \times 5 \mathrm{~m}$.sub-quadrat (Vetaas, 1997). Different samples of lichens growing on different substrata of each stand were collected separately. Herbaria of collected specimens were prepared according to methods given by Nash et al. (1993).

Lichen specimens collected during study period were identified in laboratory of Central Department of Botany, T. U. Kirtipur. Each specimen was identified in respect of their morphology, anatomy, colour reaction, thin layer chromatography, microcrystallography and cross checking of authentic samples deposited in Central Department of Botany .To identify each genus and species the key to Macro lichens (Awasti, 1988) and the key to Microlichens (Awasti, 1991) have been consulted.

\section{Key to families}

1. a. Thallus crustose, granular, leprose...... Chrysothricaceae

1.b. Thallus otherwise . . .2

2. a. Thallus squamulose, foliose or ribbon like to distinctly foliose.

2.b. Thallus fructicose, erect, prostrate to pendulous+-rounded in cross section or strap shaped ......................... 6

3. a. Photobiont blue green alga ......................... 4

3. b. Photobiont green alga .............................. 5

4. a. Thallus gelatinous, usually blackish homoiomerous ecoticated or corticated by 1-2 layers of cells spores transversely septate to muriform. Collemataceae

4. b. Thallus non-gelatinous, large lobed, spores transversely septate, lower surface ecorticated, often veined, apothecia situated dorsally on finger like lobules, spores transversely septate

Peltigeraceae

5. a. Thallus usually small and narrow lobed, closely adpressed to the substratum Physiaceae

5. b. Thallus broad lobed, loosely attached to the substratum ...Parmeliaceae

6. a. Thallus dimorphic with horizontal squamulose (sometimes absent) primary thallus and erect secondary podetia or pseudopodetia secondary thallus .... ... 7

6. b. Thallus otherwise ................................. 8

7. a.Pseudopodetia solid, with sqamules on it, spores transversely septate to muriform Stererocaulaceae

7. b. Podetia hollow with squamules on the surface Cladoniaceae

8. a.Thallus radial in cross-section, longitudinal axis without central cords . Ramalinaceae. 
8. b. Thallus radial in cross-section, longitudinal axis with central cord.... Usneaceae

\section{Key to the Species}

1. a. Thallus crustose, granular, leprose, yellow crust ....................................... Chrysothrix chlorina

1. b. Thallus otherwise . . .2

2. a. Thallus foliose ..3

2. b. Thallus fructicose . .25

3. a. Thallus homoiomerous

3. b.Thallus heteromerous $\ldots 4$

4. a. Thallus lacking tomentum of multicellular hyphal hairs, spores muriform, apothecia stipitate on short tubular stalk Leptogium indicum.

4. b. Thallus with tomentum of multicellular hyphal hairs, spores muriform .

5. a. Thallus tomentose on upper surface (same surface as apothecia) lower surface smooth, lobes 3-6 mm. with apothecia sub-pedicellate.

Leptogium resupinans

5. b. Thallus tomentose on lower surface ...6

6. a. Whitish stiff trichomes present on thalline exciple, thallus grey-brown to brown-black ....... Leptogium trichophorum

6. b. Trichomes absent on thalline exciple, thallus pale to dark grey . Leptogium delavayi

7.a.thallus corticated only on upper surface, photobiont blue green alga, apothecia vertical, erect ... Peltigera polydactyla.

7. b. Thallus corticated on both surface or only on upper surface, photobiont green alga .. 8

8. a. Thallus corticated on both surfaces, pycnidia present

8. b. Thallus corticated on both surface or only on upper surface, pycnidia absent

9.a. Pycnidia marginal, spores thick walled, more than $10 \mathrm{~cm}$. Long, apothecia perforate, marginally ciliate, rhizinae simple to bifurcate ....

Parmelaria thomsonii

9.b. Pycnidia laminal or unknown, spores simple or septate apothecia imperforate, much variable in size of lobes and colour of thallus

10

10. a. Thallus distinctly pseudocyphellate, lower surface with black rhizinae upto the edge of the lobes, medullaK+ red (salazinic acid present) Parmelia sulcata

10. b. Thallus lacking pseudocyphellae . .11

11. a. Rhizinae present throughout the lower surface of the thallus 12

11. b.Rhizinae restricted in central part, a broad marginal area lacking rhizinae 13

12. a. All or most of rhizinae dichotomously branched, medulla KC.

Parmelia flexilis
12. b. All rhizinae simple or squarrosely branched 18

13. a. Thallus isidiate

13. b. Thallus lacking isidia 15

14. a. Margins of lobes ciliate Parmelia wallichiana

14. b. Margins of lobes lacking cilia Parmelia tinctorum 15. a. Thallus pustulate 16

15. b.Thallus lacking pustules, medulla $\mathrm{KC}^{+}$red ...... Parmelia nilgherensis

16. a. Margins of lobes lacking cilia Parmelia reticulata

16. b. Margins of lobes ciliate . 17

17. a. Medulla $\mathrm{K}^{+}$red (salazinic acid present) . Parmelia stuppea

17. b. Medulla K-(salazinic acid absent) ... Parmelia santae-angeli

18. a. Lower surface naked or with long scattered rhizinae Parmelia cirrhata

18. b. Lower surface uniformly rhizinate, rhizinae short marginal . Parmelia nepalensis

19. a. Thallus sub-orbicular, appressed to substratum, lower cortex present or absent

19. b Thallus ribbon like or rosulate, attached to substratum by basal or central parts, lower cortex absent 24

20. a. Thallus corticated on both surface, rhizinae on lower surface and margin

20. b. Thallus lacking lower cortex, rhizinae absent on lower surface but present along the margin, apothecia punctate Heterodermia punctifera

21a.Thallus isidiate, sorediate

21. b. Thallus lacking isidia and soredia, apothecia upto $7 \mathrm{~mm}$. diam., margin crenulate to lacinulate ... Heterodermia diademata

22. a. Thallus with sub-isidial, marginal squamules becoming sorediate, apothecia rare Heterodermia dissecta

22. b. Thallus sorediate, isidia absent, medulla $\mathrm{K}+$, yellow 23

23. a. Soralia capitate on lateral branches, apothecia upto 8 mm.diam.laciniae $1.5 \mathrm{~mm}$. Heterodermia speciosa

23. b. Soralia capitate on lateral branches, apothecia upto3mm. diam., marginally sorediate ...... Heterodermia pseudospeciosa

24. a. Thallus ribbon like, linear with black rhizinae along margin Heterodermia leucomela

24. b. Thallus rosulate, lobes sub erect, spatulate, white cilia absent on the upper surface Heterodermia incana

25. a. Thallus, podetia or pseudopodetia solid ..................... 26

25. b. Thallus, podetia hollow center 29

26. a. Thallus dimorphic with horizontal squamulose (some- 
times absent) primary thallus and erect secondary podetia or pseudopodetia secondary thallus. Stereocaulon coniophyllum

26. b. Thallus otherwise 27

27. a. Thallus pseudocyphellate Usnea thomsonit

27. b. Thallus lacking pseudocyphellae 28 28. a. Thallus isidiate, lacking soredia ......... Usnea aciculifera 28. b. Thallus lacking isidia and soredia ...... Usnea orientalis 29. a. Prominent part of thallus podetial in nature, with or squamules 30

29. b. Prominent part of thallus podetial in nature, lacking squamules .... ... 31

30a.Podetia lacking cups, podetia soredia Cladonia coniocraea

30.b. Podetia with cups, podetia esorediate Cladonia ramulosa

31. a. Thallus much flattened longitudinally veined, palmately laciniate . Ramalina sinensis

31. b. Thallus narrow, ribbon like, less than $1 \mathrm{~mm}$. wide .. Ramalina usnea

\section{Enumeration of the species}

1. Peltigera polydactyla (Neck.) Hoffm; Bot. Mag. Tokyo 35:45, 1921.Baniya et al.; Environ. \& Agr.1 (2):51; 2001.Peltigeraceae

Thallus foliose, photobiont blue-green algae, muscicolous, corticated only on upper side, apothecia marginal, spores hyaline.

Chemical constituents - Tenuionin and Dolichorrhizin .

Distribution: - Nepal and India.

Specimen examined: -Phulchowki hill (1600m.CKB44, 2000m. CKB90; TUCH).

2. Parmelia cirrhata Fr. Syst. Orb. Veget. 1:383, 1825; Sharma In Majupuria's Nepal Nature's Paradise, p. 220; 1999.Bania et al.; Environ. \&Agr.1 (2): 51; 2001.Parmeliaceae

Thallus corticolous, lignicolous, loosely adnate to the substratum, margin ciliate foliose, grey to dark grey, lobes linear, elongate, apically tapering, upper surface smooth, rhiziniae absent, ciliate, apothecia marginal to laminal, sessile to short stalked, $2-7 \mathrm{~mm}$. in diam. margin entire, disc dark brown.asci 8-spored, spores hyaline.

Chemical constituents -Altranorin, Salacinic acid and protolichesterinic acid.

Distribution: - Nepal (Kaski, Kathmandu), India.

Specimen examined: - Phulchowki hill (1500m CKB10 TUCH).
3. Parmelia nepalensis Tayl. London J. Bot. 6:172, 1847; Sharma In Majupuria Nepal Nature's Paradise, p.220; 1999, Bania et al, Environ \& Agr. 1(2): 51, 2001; Parmeliaceae

Thallus corticolous, foliose, loosely adnate to the substratum sub erect to pendulous, grey to dark grey, 4$9 \mathrm{~cm}$. in size, margin ciliate, cilia simple to branched, isidia and soredia absent, lower side black in older part, pale brown to brown near the apices, rhizinate, rhizinae simple, squarrosely branched to dichotomously, apothecia laminal shortly stalked, disc brown to dark brown, asci 8spored, spores hyaline and simple.

Chemical constituents: -Atranorin, Salacinic acid and protolichesterinic acid.

Distribution: - Nepal (Sikles, Shivapuri,) India, Pakistan.

Specimen examined: - Phulchowki hill (1600m, CKB8; 1800m, CKB9; TUCH)

4. Parmelia nilgherrensis Nyl, Flora, 52:299, 1869, Sharma In Majupuria, Nepal Nature's Paradise p.217, 1999.Bania et al. Environ. \& Agr. 1(2): 51, 2001; Parmeliaceae

Thallus corticolous, foliose, grey. Closely to loosely adnate to the substratum, large maculate thallus, $3-18 \mathrm{~cm}$. across, ciliate, cilia 1-3mm long, simple, isidia, soredia absent, lower surface wrinkled, black, sparsely rhizinate in groups, rhizinae slener, simple, 4-8mm wide, medulla white, apothecia large, usually plenty, upto $16 \mathrm{~mm}$. in diam, imperforate, disc brown, smooth, asci 8-spored, spores hyaline.

Chemical constituents: - Atranorin, Alectoronic acid $\alpha$ collatolic acid.

Distribution: - Nepal (Sikles, Kathmandu), India, and Pakistan.

Specimen examined: Phulchowki hills (1750m, CKB12, CKB13; 1900m, CKB 24; 2000m, CKB 105; TUCH)

5. Parmelia reticulata Tayl, In Mack, Fl. Hibern. 2:148, 1836.Sharma In Majupuria, Nepal Nature's Paradise, p.220; 1999.Bania et al, Environ. \& Agr.1 (2): 51,2001. Parmeliaceae

Thallus corticolous, foliose, loosely adnate to the substratum, 4-16cm. in diam., mineral grey to dark grey, lacinate lobate, lobes rotund, imbricate, 4-8mm wide, ciliate, cilia 1-2mm long, sparce, upper surface with distinct maculate, sorediate, lower surface black towards center and brownish towards periphery, rhizinae sparse in group, apothecia laminal, upto $5 \mathrm{~mm}$ in diam, disc dark brown, imperforated, asci 8-spored, spores hyaline and simple.

Chemical constituents: Atranorin, Salacinic acid.

Distribution: -Nepal and India 
Specimen examined: -Phulchowki hills (1600m No.CKB17, CKB29, CKB38; 2200m, CKB150; TUCH)

6. Parmelia sancti-angelii Lynge, Ark. F. Bot. 13(13): 35, 1914; Sharma In Majupuria Nepal Nature's Paradise, p. 220; 1999. Bania et al. Environ. \& Arg. 1(2): 51, 2001.Parmeliaceae

Thallus corticolous or terricolous, foliose, loosely adnate to the substratum, $2-4 \mathrm{~cm}$. in size, thick ashy grey to dark grey, lobes 5-20mm. wide sub-arbicular to orbicular, margin ciliate, simple to bifurcate, 2-3mm. long, tapering, upper surface plane, emaculate, smooth, sorediate, lower surface blackish, minutely wrinkled, rhizinate, thallus sterile.

Chemical constituents: - Gyrophoric acid and Atranorin.

Distribution: - Nepal (Shivapuri, Namobuddha) and India.

Specimens examined: Phulchowki hills (1800m, CKB55, CKB56; 1900m.CKB 68, CKB70; TUCH)

7.Parmelia tinctorum Nyl, Flora, 55: 547, 1872; Sharma In Majupuria Nepal Nature's Paradise, p.220, 1999, Bania et al. Environ. \&Agr. 1(2): 51, 2001. Parmeliaceae

Thallus corticolus, foliose, loosely to closely adnate to substratum, ashy grey to grey, lobes $5-10 \mathrm{~cm}$. wide margin entire to wavy, eciliate, isidiate, isidia simple, isidia in the central part of thallus, lower side minutely wrinkled, rough, black, sparsely rhizinate in the central part, marginal, about $10 \mathrm{~mm}$ wide zone, apothecia not seen in the specimen examined.

Chemical constituents: - Atranorin and Lecanoric acid.

Distribution: - Nepal and India.

Specimen examined: - Phulchoki hill (1550m, CKB11, CKB14; 1700m, CKB54, CKB59; TUCH).

8. Parmelia wallichiana Tayl. London J. Bot. 6:176, 1847; Sharma In Majupuria Nepal Nature's Paradise, p.221, 1999; Bania et al. Environ. \& Agr. 1(2): 51, 2001.Parmeliaceae

Thallus corticolous or saxicolous, foliose, loosely adnate to the substratum, 4-6 cm. in size, margin entire, ciliate, cilia simple, usually on notches, dark grey to whitish grey, rounded margin, isidiate, isidia denser towards the central parts upper surface smooth to shiny, apothecia not seen in examined specimens.

Chemical constituents: - Atranorin and Salacinic acid.

Distribution: -Nepal, Eastern Himalayas and India.

Specimen examined: Phulchowki hills (1850m, CKB80; 1900m CKB88, TUCH)

9. Parmelia sulcata Tayl. In Mack; Flora Hibernica, 2:145, 1836; Bania et al., Environ. \& Agr. 1(2):51, 2001;

\section{Parmeliaceae}

Thallus corticolous, foliose, loosely attached to the substratum, rosette form, $5-11 \mathrm{~cm}$. in diam. bluish grey, irregularly lobate, upper surface dull, smooth, maculate lobe apices, pseudocyphellate, sorediate, lower side black, densely rhizinate upto the margin, rhizinal papillae along the margin, simple rhizinae, apothecia absent in all the specimens examined.

Chemical Constituents: Atranorin, Salacinic acid and Protocetraric acid.

Distribution: -Nepal, India and Pakistan.

Specimens examined: -Phulchowki (2100m, CKB105; TUCH).

10. Parmelia stuppea Tayl. Lond. J. Bot. 6:174, 1847; Bania et al. Environ. \&Agr. 1(2): 51, 2001; Parmeliaceae

Thallus corticolous, foliose, loosely adnate to the substratum, rosette form, $5-11 \mathrm{~cm}$ in diam. bluish grey irregularly lobate, upper surface dull, smooth, large, whitish grey, rotund, margin entire, eciliate, emaculate, isidiate, isidia in the central part of the thallus, lower side minutely wrinkled rough, black, apothecia not seen in the observed specimen.

Chemical constituents: - Atranorin and Salacinic acid.

Distribution: - Nepal (Kathmandu, Kavrepalanchok) and India.

Specimens examined: - Phulchowki hill (2200m, CKB160; TUCH)

11. Parmelia flexilis Kurok. In Hara, The flora of Eastern Himalaya, 607,1966;Sharma, In Majupuria, Nepal Nature's Paradise p.220, 1999; Bania et al. Environ \& Agr. 1(2): 51; 2001. Parmeliaceae

Thallus corticolous, foliose, closely adnate to the substratum, margin crenate, whitish grey lead grey to ashy grey, irregularly sinuate, lobes irregular, lobes 2-5mm. wide, margin eciliate, crenate, upper surface smooth, isidia, soredia absent, lower surface pale to blackish, densely rhizinate upto the margin, rhizinae dichotomously branched, apothecia common, laminal, sessile, 2-5mm.in diam. adnate, asci 8-spored, spores hyaline.

Chemical constituents: Atranorin and protolichesterinic acid .

Distribution: - Nepal and India.

Specimen examined: - Phulchowki hill (1700m, CKB80; TUCH)

12. Parmelaria thomsonii (Stirt) Awas. Journ. Hattori Bot. Lab. 63:368-370, 1987; Bania et al. Environ. \& Agr. 1(2): 51, 2001. Parmeliaceae 
Thallus corticolous, foliose, loosely attached to the substratum, ashy grey to grey, very long $15 \mathrm{~cm}$. rolled around the bark trees, irregular in outline, variable in size of lobes peripheral lobes often free from the substratum, 5-10mm wide, marginally ciliated, rhizines simple to bifurcate, apothecia sub- marginal to laminal, centrally perforated, disc reddish brown margin entire, asci 8-spored, spores hyaline and simple.

Chemical constituents: - Alectoronic acid and $\alpha$-collatolic acid .

Distribution: -Nepal and India.

Specimens examined: -Phulchowki hills (2500m, CKB205; TUCH)

13. Cladonia coniocraea (Flor.) Spreng. Syst. Veg. Linn. ed. 16, 4:277 1827; Bania et al. Environ. \& Agr. 1(2):51, 2001; Cladoniaceae

Having primary squamules irregularly incised lobe, podetia cylindrical, tapering apically with pointed ends.

Chemical constituents: - Fumarprotocetraric acid

Distribution: - Nepal, India and Bhutan

Specimen examined: -Phulchowki hills (1600m.CKB45; 1800m, CKB65; TUCH)

14. Cladonia ramulosa (Ach) Laundon, Lichenologist, 16(3): 211-239,1984; Bania et al. Environ. \& Agr. 1(2): 51, 2001.Cladoniaceae.

Having persistent primary squamules, irregularly lobed, podetia cup bearing, simple, cylindrical and branched irregularly.

Chemical constituents: - Fumarprotocetraric acid .

Distribution: - Nepal, India and Pakistan.

Specimen examined: - Phulchowki hill (1650m, CKB38; TUCH).

15. Heterodermia diademata Tayl. J. Bot. London, 6:165, 1847; Sharma In Majupuria Nepal Nature's Paradise p. 217.1999.Bania et al Environ. \& Agr. 1(2): 52, 2001; Physciaceae

Thallus loosely attached to the substratum, grayish white, lobes dichotomously to irregularly branced isidia, soredia absent, laciniate, laciniae 0.5 -2mm. wide, apothecia common, laminal, sub sessile to sessile, $2-7 \mathrm{~mm}$. in diam. margin entire to crenate, crowed in the center or scattered.

Chemical constituents: - Atranorin and Zeorin .

Distribution: - Nepal, India, China and sub alpine region of the world.

Specimen examined: - Phulchowki hills (1600m. CKB36, CKB37; 1850m, CKB92; TUCH).
16. Heterodermia dissecta (Kurok.) Awas. Geophy. 3(1): 113116, 1973; Sharma In Majupuria Nepal Nature's paradise p.217.1999. Bania et al. Environ. \& Agr. 1(2): 52, 2001; Physciaceae

Thallus mineral greyish, closely appressed to the substratum, lobes dichotomously to irregularly brached, upper surface smooth, microphyllous, lobules and isidia marginal, dense in older parts, rhizinae sparse, black. 1.52mm. long.

Chemical constituents: - Atranorin, Zeorin, Salacinic acid and Norstictic acid.

Distribution: Nepal, India, China, Pakistan and subtropical to temperate region of the world.

Specimen examined: Phulchowki hill (1500m. CKB1, CKB2; 1600m, CKB28; TUCH)

17. Heterodermia incana (Stirt) Awas Geophy.3 (1): 113-116, 1973; Sharma In Majupuria Nepal Nature's Paradise p.217, 1999. Bania et al. Environ. \& Agr. 1(2): 52, 2001; Physciaceae

Thallus whitish grey, attached centrally to the substratum; foliose laciniate, laciniae 1-2.5mm apothecia wide, sub erect, upper surface smooth, isidia and soredia absent, marginal, shortly stalked, constricted at the base, 1$6 \mathrm{~mm}$. in diam. margin distinct, crenate to lobulate.

Chemical constituents: - Atranorin and Zeorin.

Distribution: - Nepal, India, Pakistan and China.

Specimens examined: -Phulchowki hills (2300m. CKB190, TUCH).

18. Heterodemia leucomela (L.) Massal, Mem. Lich 35, 1853; Sharma In Majupuria Nepal Nature's Paradise p. 217, 1999. Bania et al. Environ. \& Agr. 1(2): 52, 2001; Physciaceae

Thallus mineral grey, loosely attached to the substratum, lobes dichotomously branched, sometime sorediate, rhizinate, and rhizinae along margins only, simple to squarrosely branched, apothecia not seen in observed specimens.

Chemical constituents: - Atranorin, Zeorin, Salcinic acid.

Distribution: - Nepal and tropical and temperate region of the world.

Specimen examined: - Phulchowki hills (1800m. CKB90, TUCH).

19. Heterodermia pseudospeciosa (Kurok) W.Culb.Broyologist 69:484, 1966; Anaptychia pseudospeciosa Kurok, J. Jap. Bot. 34:176, 1959.Sharma In Majupuria, Nepal Nature's paradise, p. 217, 1999. Bania et al., Environ. \& Agr. 1(2): 52, 2001; Physciaceae 
Thallus corticolous, foliose, closely adnate to the substratum $2-3 \mathrm{~cm}$. in size mineral grey to grey, margin wavy to lobulate, upper surface smooth, marginally soraliate lower surface white to light brown, rhizinate, rhizinae squarrosely branched, thallus sterile.

Chemical constituents: - Atranorin, Zeorin and Salacinic acid.

Distribution: - Nepal, India, China and Japan.

Specimens examined: - Phulchowki hill (1950m CKB110; TUCH).

20. Heterodermi punctifera (Kurok.) Awas, Geophy: 3(1): 114, 1973; Sharma In Majupuria Nepal Nature's Paradise, p.217; 1999. Bania et al., Environ. \& Agr. 1(2): 52, 2001; Physciaceae

Thallus whitish grey, closely appressd to the substratum, occurring in small orbicular patches, 3-4cm.across, lobes dichotomously to irregularly branched, discrete, margin notched, apothecia common, crowed in older part, punctiform.

Chemical Constituents: - Atranorin, Zeorin and Norstictic acid.

Distribution: - Nepal, China, India and tropical regions of Himalayas.

Specimens examined: -Phulchowki hill (1550m CKB16, TUCH).

21. Heterodermia speciosa Trev. Atti Soc.Ital. Sc.Nat Milano xi: 614, 1868; Sharma In Majupuria, Nepal Nature's Paradise p. 217. 1999. Bania et al., Environ. \& Agr. 1(2): 52, 2001 Physciaceae

Thallus whitish grey sub orbicular, closely appressed to the substratum, almost to the lobe ends, ashy grey, corticated on both surface, apothecia laminal, sessile, 2$6 \mathrm{~mm}$. in diam, disc brown, asci clavate.

Chemical constituents: Atranorin and Zeorin.

Distribution: - Nepal, India and temperate regions of Himalayas.

Specimens examined: - Phulchowki hills (2600m, CKB200; 2650m, CKB215; TUCH).

22. Usnea aciculifera Vain Bot Mag. Tokyo 35:45 1921; Sharma In Majupuria, Nepal Nature's Paradise, p.223. Bania et al., Environ. \& Agr. 1(2):51, 2001.Usneaceae

Thallus corticolous, fructicose, decumbent to pendulous, $5-10 \mathrm{~cm}$. long, greenish yellow to brown, attached to the substratum by a basal disc, basal disc rounded, 3-4mm,in diam. branching sub- sympodial, convergent and more or less parallel, terete, tapering, lateral branchlets usually absent, very rarely few, apothecia absent.
Chemical constituents: Usnic acid and Stictic acid.

Distribution: -Nepal, India, China and Japan.

Specimens examined: - Phulchowki hill (1750m, CKB82, TUCH).

23. Usnea orientalis Mot. Lich. Gen. Usnea stud. Monogr Pars syst. 547(1936 -38); Bania et al., Environ. \& Agr. 1(2): 51, 2001; Usneaceae.

Thallus corticolous, fructicose, erect upto $12 \mathrm{~cm}$. tall, greenish grey to yellowish grey, densely branched, branching sympodial, tapering, lateralbranchlets sparse to dense, axis solid, terete soredia, isidia, pseudocyphellae absent, apothecia upto $6 \mathrm{~mm}$.in diam.

Chemical constituents: - Usnic acid and Salacinic acid.

Distribution: -Nepal, India, Bhutan, Central America and Japan.

Specimen examined: - Phulckowki hill (1650m, CKB83; TUCH).

24. Usnea thomsoni; Stirt. Scoot Natur 6:107, 1881; Sharma in Majupuria Nepal Nature's Paradise, p.223. Bania et al., Environ. \& Agr. 1(2): 51, 2001; Usneaceae.

Thallus corticolous, erect, 5-7cm tall, dark brown to black; basal disc blackish, upto $10 \mathrm{~mm}$. in diam, branching sympodial, main branches upto $3 \mathrm{~mm}$. in diam, slightly tapering, lateral branchlets dense, densely papillate, densely, pseudocyphellate, white, isidia and soredia absent, cortex double layered, apothecia terminal, 5-8mm. in diam.

Chemical constituents: Usnic acid and Stictic acid complex.

Distribution: -Nepal, India and Bhutan.

Specimen examined: - Phulchowki hill (2700m, CKB245; TUCH).

25. Ramalina usnea (L) Howe, Bryologist 17:81, 1914; Bania et al., Environ. \& Agr. 1(2): 51, 2001 Ramalinaceae

Thallus erect to sub pendulous, solid esorediate to sub pendulous, narrow laciniate or ribbon like thallus, nerves distinct, less than $1 \mathrm{~mm}$. broad, spirally twisted, pseudocyphellae streak-like and longitudinally parallel, apothecia $0.5 \mathrm{~mm}$. diam.

Chemical constituents: - Sekikaic acid.

Distribution: -Nepal and India.

Specimen examined: -Phulchowki hill (1700m,CKB62; 1950m,CKB132; TUCH).

26. Ramalina sinensis Jatta, Nuov. Giorn. Bot Ital. 9:462, 1902; Sharma In Majupuria Nepal Nature's Paradise p.222, 1999; Bania et al., Environ. \& Agr. 1(2): 51, 2001; 


\section{Ramalinaceae.}

Thallus erect to sub pendulous, firmly attached to the substratum by narrow basal disc, pale grey to greenish grey, branching lateral, main branches flattened, strap shaped to sinuate, secondary branching lateral, upper surface uneven longitudinally and partly reticulately wrinkled isidia, soredia pseudocyphellae absent, apothecia $2-7 \mathrm{~mm}$

Chemical constituents: - Usnic acid.

Distribution: -Nepal, India, China, Japan and Pakistan.

Specimen examined: Phulchowki hill (1600, CKB22; TUCH).

27. Stereocaulon coniophyllum Lamb. Journ Hattori Bot. Lab.27: 270, 1977. Sharma In Majupuria Nepal Nature's Paradise p.222.1999; Bania et al., Environ. \& Agr. 1(2): 51, 2001 Stereocaulaceae

Pseudopodetia sorediate, upto $5 \mathrm{~cm}$. tall, robust, rigid, cephalodia subglobose to pyriform in outline, corrugate on surface, with well developed gelatinized cortical tissue, sub globose to pyriform in outline.

Chemical constituents: - Atranorin and Lobaric acid .

Distribution: - Nepal, Bhutan and India.

Specimen examined: -Phulchowki hill (1500m, CKB6; TUCH).

28. Chrysothrix chlorina (Ach.) Laundon, Lichenologist, 13(2): 106- 110, 1981; Bania et al, Environ. \& Agr.1 (2): 52; 2001.Chrysothricaceae

Thallus thick, yellow crust, corticolous. Granules $0.1-0.2$ mm.diam forming pulverulent mass.

Chemical constituents: Calyan and Vulpinic acid.

Distribution: - Nepal, common in N-W himalaya.

Specimen examined: -Phulchowki hill (2700m, CKB220; TUCH).

29. Leptogium delavayi Hue, Bull. Soc. Bot. France, 36:25, 1889; Bania et al., Environ. \& Agr. 1(2): 51, 2001 Collemataceae

Thallus corticolous, as well as muscicolous on bark and stone, foliose, $1.5-4 . \mathrm{cm}$. in size, closely attached to the substratum dark grey to pale grey in dry, upper surface smooth, densely tomentose isidia, soredia absent, apothecia sub marginal to laminal, 2-6mm. in diam., pedicel tubular reddish brown, spores transversely 4-5 septate.

Chemical constituents: - No lichen substances.

Distribution: - Nepal and India.

Specimens examined: - Phulchowki hills (1700m.CKB66; TUCH)
30. Leptogium resupinas. Nyl, Annal Soc. Nat Bot 15(4). 368, 1861; Bania et al., Environ. \& Agr. 1(2): 51, 2001 Collemataceae

Thallus foliose, upto $3 \mathrm{~cm}$. in size, ashy grey when dry, olive green when wet loosely attached to the substratum, lobes 3-6mm. wide, submarginal to laminal, constricted at base to shortly pedicellate, $0.5-1.5 \mathrm{~mm}$. in diam. disc reddish brown, ascus 8-spored.

Chemical constituents: - No lichen substances.

Distribution: - Nepal, India, Bolivia and east Africa.

Specimens examined: - Phulchowki hill (1900m, CKB114; 2100m. CKB123; TUCH).

31. Leptogium indicum Awas. \&. Akhtar, Geophy: 8(2): 191198, 1979; Bania et al., Environ. \& Agr. 1(2): 51, 2001 Collemataceae

Thallus foliose, 3-6cm in size, light to dark lead grey when dry, olive green when wet, irregularly lobate, 4-9mm. wide, apothecia dense, pedicellate, laminal to sub marginal, stalk uniformly tubular, 0.5 to $1.5 \mathrm{~mm}$. long. Asci 8-spored, hyaline.

Chemical constituents: - No lichen substances.

Distribution: -Nepal, India and Pakistan.

Specimens examined: -Phulchowki hill (1800m. CKB95; TUCH).

32. Leptogium trichophorum Mull Arg. Flora 72: 505. 1889; Bania et al., Environ. \& Agr. 1(2): 51, 2001; Collemataceae

Thallus foliose, upto $5 \mathrm{~cm}$ in size, loosely attached to the substratum, grey brown to brown black when dry, dark olivaceus green when wet, isidia soredia absent, apothecia sub marginal to laminal, sessile $0.5-2 \mathrm{~mm}$ in diam asci laminal, dense trichomes on thalline exciple.

Chemical constituents: - No lichen substances.

Distribution: - Nepal, India, Philippines and widely distributed in eastern Asia.

Specimens examined: - Phulchowki hill (1750m CKB76; TUCH).

\section{RESULTS AND DISCUSSION:}

Thirty-two specimens of lichens (foliose and fructicose) were found in present study. These species belong to ten genera in which genus Parmelia consists of maximum number of species (ten species) where as three genera consist of only one species each. Similarly these lichen flora studied consist of nine families in which family Parmeliaceae was largest.

In conclusion Phulchowki hill is rich in lichen flora especially of foliose and fructicose form. Between these two forms, foliose forms are found in large amount. Among them genus 
Parmelia was largest which includes ten species. Genera Parmelaria, Chrysothrix, Peltigera and Stereocaulon contain single species each.

\section{REFERENCES:}

Awasti, D.D. 1988. A Key to the Macro lichens of India and Nepal.Journ. Hattoria Bot.Lab. No.65: 207-302.

Awasti, D.D. 1990. A Key to the Microlichens in India, Nepal and Sri Lanka.Bibliotheca Lichenologica 40:1-336.

Bania, C.B.1996. The Floristic Composition of Lichens in Sikles (Kaski) and Shivapuri (Kathmandu) and Ecology. Thesis submitted for the partial fulfillment of the requirement of the Master's Degree in Botany.

Bania, C. B., Ghimire G.P.S., Kattel, B. and Upreti D.K. 2001. Lichens in Sikles (Kaski) and Shivapuri (Kathmandu), Nepal. In: Environment and Agriculture: Biodiversity, Agriculture and Pollution in South Asia (eds.) Jha, P.K., S. R. Baral S.B. Karmacharya, H. D Lekhak, P.Lacoul and C.B. Baniya.Ecological Society (Ecos.) Nepal.pp 49-55.

Devkota, A. 1999. Study of Floristic Composition and antibiotic property of some lichen species in Namo Buddha (Kavrepalanchok). Thesis submitted for the partial fulfillment of the requirement for the Master's Degree in Botany.

Hawk worth, D.L. and Hill, D. J. 1984. The Lichen Forming Fungi.Blacie and Son Ltd.Glasgow, 1-158.
Lamb, I.M. 1963. Index Nominum Lichenum.Ronald Press, New York.255pages

Nash, T.H., Wetmore, C.M., Anderson, W., Brat, C., Denison, C., Eversman, S., Murray, B., Clari, L. (1993) Floristics.Lichens as Bioindicators of Air Quality, U.S. Department of Agriculture, Fort Collins, Colorado, General Technical Report, RM-224, 6-15.

Pathak, R. 1998. The Floristic Composition of Lichens and their biodiversity in Hetauda and Dang. Thesis submitted for the partial fulfillment of the requirement of the Master's Degree in Botany.

Rogers, R.W. 1988. Ecological Strategies of Lichens. Lichenologist 22:149-162.

Sharma, L.R .1995. Enumeration of the lichens of Nepal.W.J.M.Verheught (ed.) Ministry of Forest and Soil Conservation and Department of National Parks and Wildlife Conservation Research report. Publ. No. 3-111.

Sharma, L. R.1999. Lichens.In: Nepal Nature's Paradise. (eds.), Majupuria, T.C, and Majupuria, R. K.Publ.M. Devi, Gwalior, (India), pp.212-223.

Vetaas, Ole R. 1997. Effect of Canopy disturbance on species richness in a central Himalayan Oak forest. Plant Ecology.132-38.

Zahlbruckner, A.1922-1940. Cataiogus Lichenum Universalis. Borntraeger, Leipzig. 